\title{
How much walnut husk fly (Rhagoletis completa Cresson) affects nut quality of different walnut cultivars?
}

\author{
A. Solar ${ }^{1}$, F. Stampar ${ }^{2}$, R. Veberic ${ }^{2}$ and S. Trdan ${ }^{3}$ \\ ${ }^{1}$ University of Ljubljana, Biotechnical Faculty, Department of Agronomy, Experimental Field for Nut Crops, Maribor, Slovenia \\ ${ }^{2}$ University of Ljubljana, Biotechnical Faculty, Department of Agronomy, Chair for Fruit, Wine and Vegetable Growing, \\ Ljubljana, Slovenia \\ ${ }^{3}$ University of Ljubljana, Biotechnical Faculty, Department of Agronomy, Chair of Phytomedicine, Agricultural Engineering, \\ Crop Production, Pasture and Grassland Management, Ljubljana, Slovenia
}

\begin{abstract}
Summary
Introduction - Since the occurrence of walnut husk fly (WHF) is associated with significant yield and nut quality losses, a detailed information on cultivars' susceptibility is essential for profitable production of common walnut. Materials and methods - Seven pomological traits related to external nut quality and five traits describing kernel quality were observed in $\mathbf{1 0}$ commercial cultivars to determine WHF-damage level. Results and discussion - The damage was cultivarand infestation time-related. It was shown by reduced nut weight within a range from $0.1 \mathrm{~g}$ ('Elit') to $1.9 \mathrm{~g}$ ('Franquette'), by an increased number of baby nuts from $1.4 \%$ ('G-139') to $18.1 \%$ ('Chandler') and by a higher ratio of empty nuts ranging from $0 \%$ ('G-139') to $12.5 \%$ ('Fernette'). Internal damage was represented as kernel weight reduction within a range of $0.1 \mathrm{~g}$ ('A-117') to $1.2 \mathrm{~g}$ ('Franquette') and as reduced kernel percentage from $0.2 \%$ ('G-139') to $7.0 \%$ ('Chandler'). Between 5.3\% ('A-117') and 50.0\% ('Chandler') of the kernels had more than a half of their surface darkened, and totally black kernels appeared within a range of $4.0 \%$ ('A-117') to $36.1 \%$ ('Chandler'). Early WHF infestation caused shriveled kernels, which varied from $0 \%$ in 'G-139' to $30.6 \%$ in 'Cisco' and 'Chandler' cultivars, together with kernel mouldiness, ranging from $37 \%$ ('Fernette') up to $\mathbf{7 5 \%}$ ('Elit') mould. Infested 'Fernor' preserved the best external and internal quality, while 'Franquette' and 'Chandler' showed the highest WHF damage levels. Conclusion - The results may be taken into consideration when planting new walnut orchards, and suggest favouring less susceptible cultivars.
\end{abstract}

Keywords

cultivars, WHF damage, Juglans regia L., Rhagoletis completa Cresson, Diptera: Tephritidae

\section{Introduction}

Walnut (Juglans regia L.) is the most widespread tree nut in the world, commercially cultivated throughout southern Europe, northern Africa, eastern Asia, the USA and western South America (Martinez et al., 2010). It is highly appreciated as a raw nut for fresh consumption as well as for use in the food industry. Walnut kernels are valued for their nutritional, health and sensory attributes. They are a nutrient-dense food

\section{Significance of this study}

What is already known on this subject?

- Walnuts are nutritionally valuable food with many health beneficial effects. Their production is strongly affected by walnut husk fly (WHF). Significant crop losses due to the pest is recognized world-wide. Detailed information on the infestation impact on external and internal nut quality of cultivars grown in continental climate is still insufficient.

What are the new findings?

- Due to the WHF infestation, both in-shell walnut and kernel quality was affected, showing as reduced nut and kernel weight and kernel percentage, empty nuts, dark shells and kernels as well as shriveled and mouldy kernels. The damage was shown as cultivarspecific and related to the time of WHF infestation.

What is the expected impact on horticulture?

- An information on natural resistance/tolerance of important commercially grown cultivars to WHF is provided for continental climatic conditions. Since efficiency of different plant protection methods is limited, the cultivar choice can present one of the most promising preventive methods for controlling the pest in question.

due to their polyunsaturated fat content, proteins, vitamins, minerals and dietary fibre (Chen et al., 2008; Cosmulescu et al., 2009; Martinez et al., 2010). They are also a good source of various bioactive compounds such as phenolics (Colaric et al., 2005; Bujdoso et al., 2014; Slatnar et al., 2015) and phytosterols (Miraliakbari and Shahidi, 2008), with potent antioxidant and health-promoting actions. As a healthy, nutritionally valuable food, walnuts deliver nutritional attributes in servings of 1.5 ounces and 30-42 g, respectively, which is the daily intake recommended by the US Food and Drug Administration (2018) and the Australian tree nut industry (2018).

There is strong scientific evidence of the positive effects of a dietary intake of walnuts on human health, performance and diseases. Regular walnut consumption is associated with a reduction in the risk of cardiovascular diseases (Ros, 2015) and neurodegenerative disorders (Carey et al., 2013), as well as some forms of cancer (Bao et al., 2013), type 2 diabetes (Pan et al., 2013) and obesity (Bes-Rastrollo et al., 2009). 
Faultless walnuts of high and stable internal and external quality are needed for the consumer to benefit from the positive health effects of walnuts. According to international quality standards (UNECE 2012), walnuts on the market should be without any visible disorders of the shell or the kernel. Pests and diseases are the most frequent causal agents that provoke such disorders and significantly affect the quality of the walnuts. The walnut husk fly, WHF (Rhagoletis completa Cresson), is the main pest affecting walnuts, causing economically important crop losses in many growing regions, including the USA and most European walnut-producing countries (Van Steenwyk and Barnett, 1998; Olson and Buchner, 2002; Duso and Dal Lago, 2006; Aluja et al., 2011).

In Europe, the WHF was first recorded in Switzerland in 1991 (Merz, 1991), followed by northern Italy a few years later (Duso and Dal Lago, 2006). From there, it spread to Slovenia, Austria and France (Solar et al., 2007; Lethmayer, 2008; Verhaeghe et al., 2010), as well as to Germany, Hungary and Croatia (Tuba et al., 2012; Guillen et al., 2011; Barić et al., 2015). The first appearance in Slovenia was noted in 1997, in the Vipava Valley in the southwestern part of the country (Seljak and Žežlina, 1999). Today, it is active all over the country. Depending on the year and location, crop losses due to WHF infestation vary from 50 to $90 \%$ (Miklavc et al., 2010).

The adult walnut husky fly has a characteristic band-pattern on its wings, which distinguishes it from other flies. Emerging from late May until early September in the USA (UC, 1993) and from early July until late September in mid Europe (Miklavc et al., 2010), it deposits eggs in green husk tissue. After hatching, the maggots feed inside the husk, turning it very soft and black. The outer skin of the husk usually remains intact, but its fleshy parts decay and stain the nutshell. A WHF infestation early in the season leads to shriveled and darkened kernels, while late infestations do little damage to the kernels but may stain the shells (UC, 1993).

There is comprehensive research work reporting on the WHF seasonal phenology and flight dynamics (Duso and Dal Lago, 2006; Tuba et al., 2012; Kasana and Aliniazee, 1996; Carsten and Papaj, 2005; Milles et al., 2015) as well as on protection measures (Hislop et al., 1981; Riedl et al., 1989; Coates and Van Steenwyk, 2005; Anderson and Lampinen, 2008; Van Steenwyk et al., 2013, 2014a, b, 2015, 2016; Sarles et al., 2015; Laznik and Trdan, 2013). Furthermore, cultivars' susceptibility to the pest has been investigated (Van Steenwyk et al., 2013, 2014a; Opp et al., 2001; Coates, 2004, 2005, 2008), while information on quality losses of the crop caused by WHF is still rare and insufficient.
In the present study, we hypothesized that the WHF infestation significantly affects both external and internal quality of walnut fruits. Large differences amongst various commercially grown cultivars were expected regarding to changes of the pomological traits of in-shell walnuts and their kernels caused by WHF. The damage level was also suspected to be dependent on the WHF-infestation time.

\section{Materials and methods}

\section{Experimental site and plant material}

The research was carried out at the walnut experimental variety collection of the Biotechnical Faculty located in Maribor (NE Slovenia, 46 $32^{\prime} \mathrm{N}, 15^{\circ} 39^{\prime} \mathrm{E}$, elevation $275 \mathrm{~m}$ ). Typical continental weather conditions with a mean year temperature of $9.7^{\circ} \mathrm{C}$, absolute summer maximum of $35.8^{\circ} \mathrm{C}$, winter minimum of $-22.3^{\circ} \mathrm{C}, 1,799$ hours of sun irradiation and $1,046 \mathrm{~mm}$ of rainfall are characteristic for this region (Solar and Stampar, 2011). At flat level, 16-23 year old trees are grown on moderately acid, shallow soil, in a non-irrigated orchard, modestly fertilized with nitrogen, potassium and phosphorus. Grass is maintained between the rows and herbicide is used within the rows. Except for periodical sprayings against walnut blight (Xanthomonas arboricola pv. juglandis), no other chemicals are applied to control pests and diseases.

Ten cultivars of different origin were included in the analysis: 'Alsoszentivany-117' (A-117) from Hungary; 'Chandler' and 'Cisco' from the USA; 'Franquette,' 'Fernor', 'Fernette' and 'Lara' from France; 'G-139' from Germany; 'Rasna' from Serbia; and 'Elit' from Slovenia. Two replicates of each cultivar were observed in a randomized complete block design at a spacing of $10 \mathrm{~m} \times 10 \mathrm{~m}$.

Nuts were sampled in the years 2011 and 2012. Approximately ten days before maturation, we put plastic nets around the fruiting shoots in order to isolate the nuts and protect them from falling out from the trees. At harvest, 75 nuts of different phytosanitary status were randomly sampled from individual trees: 25 nuts without any visible symptoms of WHF attack (healthy - H, Figure 1); 25 nuts with small darkened lesions on the green husk caused by WHF that emerged in early September (late infestation - L, Figure 1); and 25 nuts with intact, but completely darkened and softened husk, owing to early WHF attack in mid-August (early infestation - E, Figure 1). Since the nuts were taken from two trees per cultivar, $50 \mathrm{H}, \mathrm{L}$ and $\mathrm{E}$ in-shell nuts were sampled for each of the ten studied cultivars $(1,500$ nuts in total).

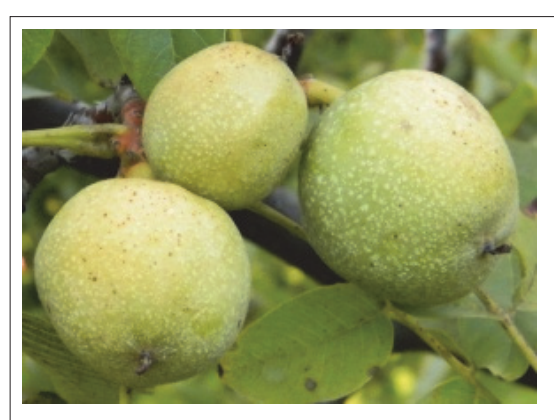

Healthy $(\mathrm{H})$

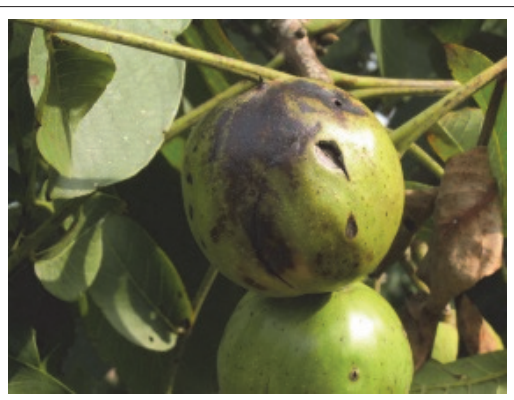

Late infestation (L)

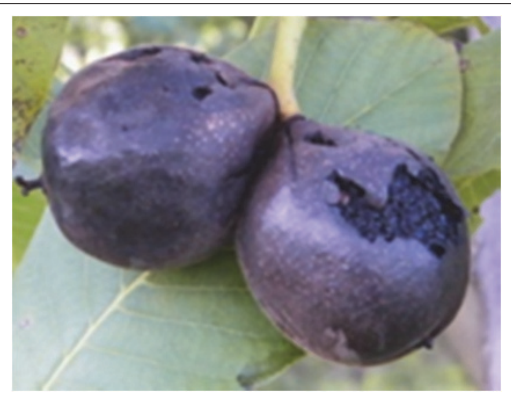

Early infestation (E)

FIGURE 1. Phytosanitary status of the sampled walnuts: healthy without WHF-infestation (H), late-infested (L) and earlyinfested (E). 
Nuts within the nets were taken from the trees at the stage of technological maturation. Softened and blackish husks from both late- and early-infested nuts were removed by water-washing under high pressure. All the nuts (50 per each phytosanitary status per cultivar) were then dried in circulated airflow in a wooden three-stage dryer at $35^{\circ} \mathrm{C}$ to approximately $12 \%$ moisture content. Each sample was then randomly divided into two subsamples of 30 and 20 nuts, followed by storing in a cool room at $10^{\circ} \mathrm{C}$ in net bags until analyses.

\section{Pomological characterization}

Thirty in-shell nuts per phytosanitary status (H, L, E) were observed for their pomological characteristics in each cultivar. Their length, width and thickness were measured in $\mathrm{mm}$, using a caliper. They were weighed using a laboratory balance, accurate to $0.1 \mathrm{~g}$. In-shell nut size was evaluated introducing three classes related to the in-shell weight, i.e., baby nuts (mean in-shell weight $\times 0.67=a$ ), extra-large nuts (mean in-shell weight $\times 1.33=\mathrm{b}$ ) and normal-sized nuts $(100-(a+b))$. The nuts were then cracked by hand. Shell thickness was measured in $\mathrm{mm}$, after cracking, on the convex side of each half using a caliper. The kernels were weighed, and the percents of the kernels were calculated as [(kernel weight / nut weight) $\times 100$ ]. Kernel fill was evaluated in order to additionally quantify the impact of the WHF on the nut's quality. Three classes were used, as follows: poor fill (mean kernel weight $\times 0.67=\mathrm{c}$ ); empty nuts (mean kernel weight $\times 0.20=d)$; and normal fill $(100-(c+d))$.

The presence of shell and kernel defects caused by the WHF were evaluated as follows:

- shell and kernel darkness, expressed in a share of

darkened shell and kernel, respectively: 1 - bright shell/

kernel; 2 - black shell/kernel up to $1 / 4$ of the surface; 3 -

black shell/kernel from $1 / 4$ to $1 / 2$ of the surface; 4 -more

than $1 / 2$ shell/kernel surface is black (Figure $2 a, b$ );

- kernel colour: 1 - bright kernel; 2 - brown kernel; 3 -

dark brown; and 4 - black kernel (Figure 2c);

- shriveled kernels: 1 - normally developed kernels; 2 -

partly shriveled; 3 - more than half of the kernel shriveled

(Figure 2d);

- mouldy kernels: 1 - absent; 2 - present.

\section{Statistical analysis}

A multifactor analysis of variance (ANOVA) was carried out to determine which factors (cultivar, infestation time, interaction) had a statistically significant influence on pomological traits among the treatments. The statistical differences between means at a 95\% confidence level were calculated using the Duncan's Multiple Range Test. For this purpose the statistic program Statgraphics Plus 4.0. (Manugistics, Inc., Rockville, USA) was used.

\section{Results and discussion}

\section{Nut and kernel quantitative traits affected by WHF}

The WHF significantly reduced nut and kernel weight, as well as kernel percentage, corresponding with earlier investigations by Opp et al. (2001), Coates and Van Steenwyk (2005), Coates (2005, 2008), Guillen et al. (2011), and Samietz et al. (2012). The reduction differed notably among the studied cultivars, which is in agreement with Opp et al. (2001), Coates (2004), and Guillén et al. (2011). The reduction appeared within a range of $0.1 \mathrm{~g}$ to $1.9 \mathrm{~g}$ for in-shell weight (up to $17 \%$ ), from $0.1 \mathrm{~g}$ to $1.2 \mathrm{~g}$ for kernel weight (up to $22 \%$ ), and from $0.2 \%$ to $7.0 \%$ for kernel percentage (Table 1). The maximum in-shell weight reduction of $17 \%$ was lower than that of $22 \%$, reported by Coates (2008), but much higher than the $5.8 \%$ ascertained in Croatia by Barić et al. (2015). As explained by Wu et al. (2009), the reduction in kernel weight could be explained by the fact that the larval feeding in the nutritient-rich parenchyma cells of the walnut husk's mesocarp inhibits a nutrient transfer to the kernel.

One of the highest susceptibility levels to WHF was found in the 'Franquette' cultivar, which had healthy in-shell nuts of $11.57 \mathrm{~g}$ compared to $11.15 \mathrm{~g}$ at late WHF infestation, and $9.62 \mathrm{~g}$ after an early infestation. Similar findings regarding 'Franquette' were published by Californian and Italian researchers. As reported by Duso and Dal Lago (2006), the 'Franquette' nuts, which were completely darkened due to WHF, had both a significantly lower in-shell and kernel weight, as well as kernel percentage. According to Van Steenwyk et al. (2013), late-season leafing cultivars, such as 'Franquette', are more susceptible than early-season leafing cultivars. In our study, such a pattern was also confirmed

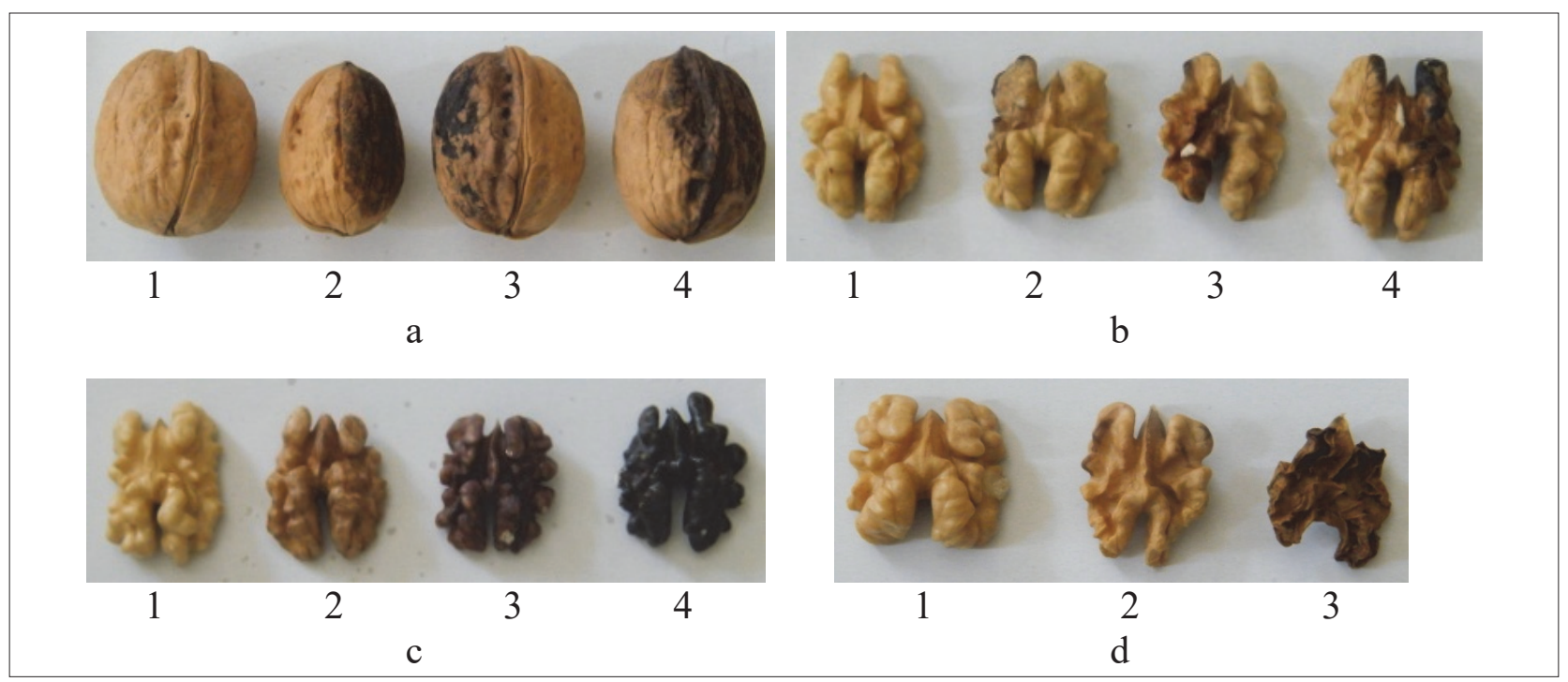

FigurE 2. Levels of shell darkness (a), kernel darkness (b), kernel colour (c), and kernel shriveledness (d) evaluated at noninfested, WHF-late infested and WHF-early infested nuts of ten walnut cultivars. 
TABLE 1. Pomological traits of nuts related to three levels of WHF infestation in ten walnut cultivars (means \pm SE).

\begin{tabular}{|c|c|c|c|c|}
\hline Cultivar & $\begin{array}{c}\text { WHF } \\
\text { infestation }\end{array}$ & $\begin{array}{l}\text { Nut weight } \\
\text { (g) }\end{array}$ & $\begin{array}{l}\text { Kernel weight } \\
\text { (g) }\end{array}$ & $\begin{array}{c}\text { Kernel } \\
\text { percentage (\%) }\end{array}$ \\
\hline A-117 & $\mathrm{H}^{*}$ & $12.93 \pm 0.20 a$ & $6.22 \pm 0.15 a b$ & $47.80 \pm 0.57 \mathrm{a}$ \\
\hline A-117 & $\mathrm{L}$ & $13.61 \pm 0.20 b$ & $6.61 \pm 0.15 b$ & $48.33 \pm 0.58 a$ \\
\hline A-117 & $E$ & $12.94 \pm 0.20 \mathrm{a}$ & $6.16 \pm 0.15 a$ & $47.07 \pm 0.57 a$ \\
\hline Chandler & $\mathrm{H}$ & $8.49 \pm 0.23 b$ & $4.01 \pm 0.15 b$ & $46.73 \pm 0.94 b$ \\
\hline Chandler & L & $8.53 \pm 0.23 b$ & $3.95 \pm 0.15 b$ & $46.45 \pm 0.94 b$ \\
\hline Chandler & $E$ & $7.45 \pm 0.23 \mathrm{a}$ & $3.07 \pm 0.15 a$ & $39.75 \pm 0.94 \mathrm{a}$ \\
\hline Cisco & $\mathrm{H}$ & $9.88 \pm 0.26 b$ & $4.18 \pm 0.17 b$ & $42.10 \pm 1.32 b$ \\
\hline Cisco & L & $9.40 \pm 0.26 a b$ & $3.76 \pm 0.17 b$ & $38.78 \pm 1.32 a b$ \\
\hline Cisco & $E$ & $8.85 \pm 0.26 \mathrm{a}$ & $3.23 \pm 0.17 a$ & $35.40 \pm 1.33 a$ \\
\hline Elit & $\mathrm{H}$ & $8.36 \pm 0.19 a b$ & $3.71 \pm 0.13 a$ & $43.29 \pm 1.09 a$ \\
\hline Elit & $\mathrm{L}$ & $8.82 \pm 0.19 b$ & $3.91 \pm 0.13 a$ & $43.30 \pm 1.09 a$ \\
\hline Elit & $E$ & $8.22 \pm 0.19 a$ & $3.64 \pm 0.13 a$ & $44.00 \pm 1.09 a$ \\
\hline Franquette & $\mathrm{H}$ & $11.57 \pm 0.23 b$ & $5.13 \pm 0.18 b$ & $43.41 \pm 1.50 b$ \\
\hline Franquette & $L$ & $11.15 \pm 0.23 b$ & $4.82 \pm 0.18 b$ & $42.77 \pm 1.48 b$ \\
\hline Franquette & $E$ & $9.62 \pm 0.23 a$ & $3.96 \pm 0.18 a$ & $38.60 \pm 1.50 \mathrm{a}$ \\
\hline Fernor & $\mathrm{H}$ & $9.24 \pm 0.23 \mathrm{a}$ & $3.84 \pm 0.28 a$ & $41.04 \pm 3.15 a$ \\
\hline Fernor & L & $9.60 \pm 0.23 \mathrm{a}$ & $4.05 \pm 0.28 a$ & $42.19 \pm 3.17 b$ \\
\hline Fernor & $E$ & $9.83 \pm 0.23 \mathrm{a}$ & $4.01 \pm 0.28 \mathrm{a}$ & $39.95 \pm 3.17 \mathrm{a}$ \\
\hline Fernette & $\mathrm{H}$ & $10.91 \pm 0.26 a$ & $4.80 \pm 0.21 a b$ & $42.78 \pm 1.58 \mathrm{a}$ \\
\hline Fernette & L & $11.65 \pm 0.26 b$ & $5.31 \pm 0.21 b$ & $45.23 \pm 1.58 b$ \\
\hline Fernette & $\mathrm{E}$ & $10.31 \pm 0.26 a$ & $4.46 \pm 0.21 \mathrm{a}$ & $41.04 \pm 1.58 \mathrm{a}$ \\
\hline G-139 & $\mathrm{H}$ & $9.33 \pm 0.20 \mathrm{a}$ & $3.91 \pm 0.10 \mathrm{a}$ & $41.41 \pm 0.42 \mathrm{a}$ \\
\hline G-139 & $L$ & $9.83 \pm 0.20 \mathrm{a}$ & $4.06 \pm 0.10 a$ & $40.90 \pm 0.42 a$ \\
\hline G-139 & $E$ & $10.91 \pm 0.20 b$ & $4.51 \pm 0.10 b$ & $41.21 \pm 0.42 \mathrm{a}$ \\
\hline Lara & $\mathrm{H}$ & $10.28 \pm 0.31 \mathrm{a}$ & $4.72 \pm 0.18 \mathrm{a}$ & $45.55 \pm 0.72 b$ \\
\hline Lara & L & $10.25 \pm 0.31 \mathrm{a}$ & $4.61 \pm 0.18 a$ & $43.89 \pm 0.73 a b$ \\
\hline Lara & $E$ & $10.81 \pm 0.31 \mathrm{a}$ & $4.82 \pm 0.18 a$ & $43.36 \pm 0.73 a$ \\
\hline Rasna & $\mathrm{H}$ & $13.04 \pm 0.30 \mathrm{a}$ & $5.92 \pm 0.21 \mathrm{a}$ & $43.55 \pm 0.93 a$ \\
\hline Rasna & L & $14.28 \pm 0.30 b$ & $6.27 \pm 0.21 \mathrm{a}$ & $43.31 \pm 0.93 a$ \\
\hline Rasna & $E$ & $13.52 \pm 0.30 \mathrm{ab}$ & $5.74 \pm 0.21 \mathrm{a}$ & $41.15 \pm 0.93 a$ \\
\hline
\end{tabular}

${ }^{*} \mathrm{H}$ - healthy nuts, without WHF infestation, $\mathrm{L}$ - late infestation, $\mathrm{E}$ - early infestation. Means with different letters within three rows related to the same cultivar are significantly different according to analysis of variance (ANOVA) and Duncan's Multiple Range Test $(P \leq 0.05)$.

in early-leafing cultivars 'A-117', 'G-139' and 'Rasna', where the weight of early-infested nuts was similar or even heavier compared to non-infested ones. In the cultivar 'Elit', WHF had almost no effect on the nut and kernel weight. As an early cultivar, which often matures before most husk fly larvae develop, 'Elit' might escape WHF infestation, confirming the findings of Van Steenwyk and Barnett (1998) and Opp et al. (2001), who noticed a correlation between maturation time and WHF-damage levels.

Infestation-time effect was also clearly expressed, showing that an early WHF attack caused a greater decrease in nut and kernel weight as well as kernel percentage compared to a late attack. Mean data for 10 studied cultivars even showed that late-infested nuts only slightly differed from non-infested ones in their kernel weight and kernel percentage (Figure $3)$. Moreover, late-infested in-shell nuts were even significantly heavier than non-infested ones. These results compare favourably with Coates (2008) who reported that WHF damage occurring later in the season resulted in no loss of mean nut weight.

Early infestation generally resulted in a higher percentage of baby nuts compared to non-infested nuts $(9 \%$ vs.
$5.5 \%)$ and also a lower percentage of normally developed nuts ( $83 \%$ vs. $89 \%)$. Besides a phytosanitary status, a strong cultivar influence on the share of baby and extra-large nuts was determined (Figure S1). At late infestation, the cultivars 'Cisco' and 'Chandler' developed 16.2 and $15.3 \%$ of baby nuts, respectively (Figure S1b). Early infestation led to an increased share of baby nuts not only in 'Chandler', with $18.1 \%$, but also in 'Fernette' with $15.1 \%$ and in 'Franquette' and 'Lara' cultivars with $16.7 \%$.

A relationship between the phytosanitary status of the nuts and the kernel fill was also proved. As Figure 5 shows, early infestation significantly decreased the share of normally filled kernels and increased the number of empty nuts with very small kernels. At late infestation the 'Cisco' cultivar comprised a total $21.6 \%$ of poorly filled and empty nuts (Figure S2b). Early infestation had a stronger impact on kernel fill. The 'Franquette' cultivar was the most affected, having one-third of poorly filled and empty nuts (Figure S2c). It was followed by 'Lara' and 'Cisco' with 23.6\%, and 'Chandler' and 'Fernette' with $22 \%$ of poorly filled and empty nuts.

Furthermore, our study shows that shell thickness appeared in almost equal values in both infested and non-in- 


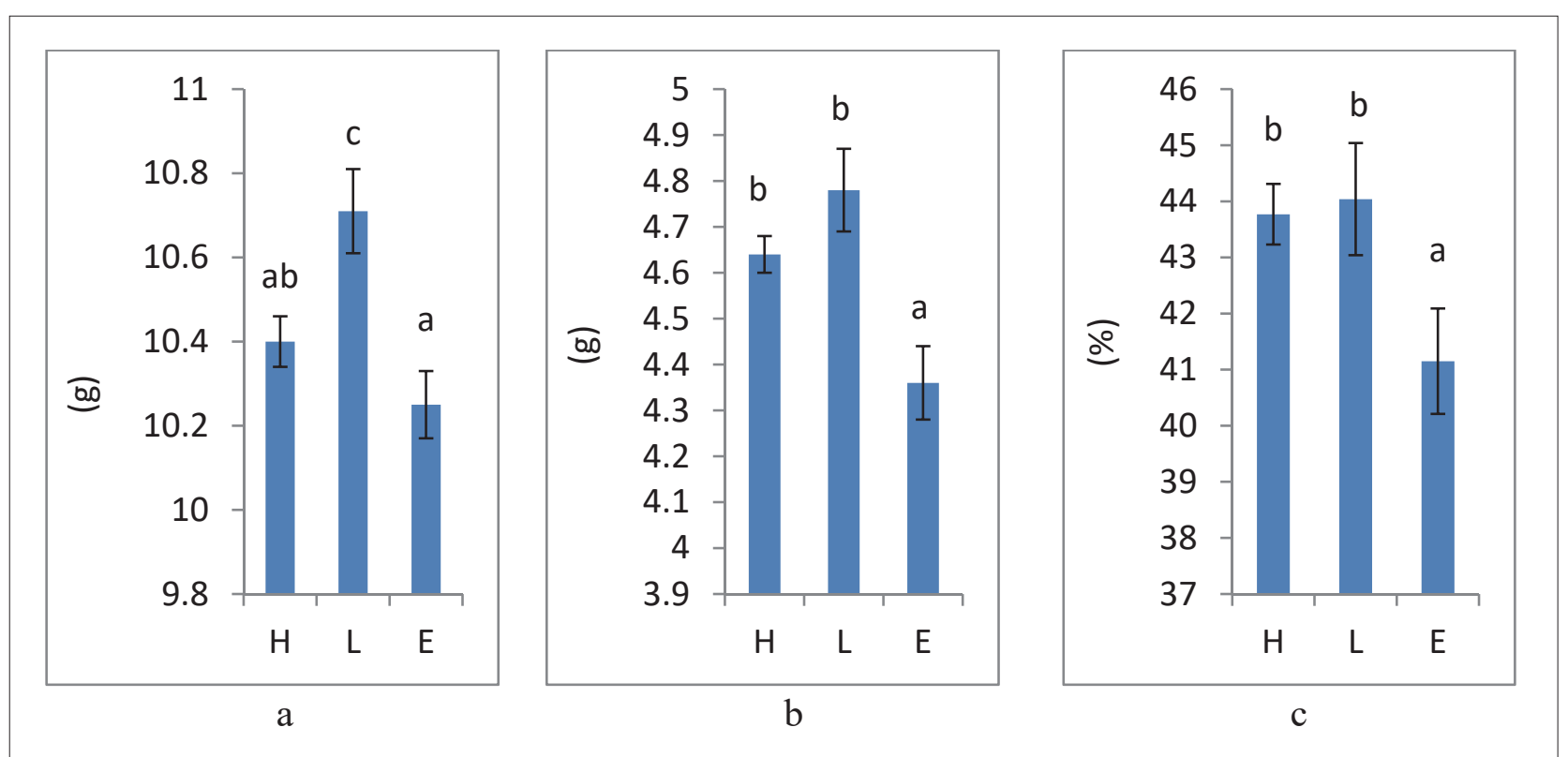

FIGURE 3. Nut weight (a), kernel weight (b), and kernel percentage (c) of the nuts (means \pm SE) of different phytosanitary status regarding WHF: H (healthy, non-infested), L (late season-infested), E (early season-infested) for ten walnut cultivars. Different letters in each column represent statistically significant differences of a single trait at different phytosanitary status at $\mathrm{p} \leq 0.05$.

fested nuts. There were only two exceptions, i.e., the late-leafing and late-maturing cultivars 'Franquette' and 'Fernette', where early WHF infestation resulted in the thinnest shells (Table 1).

\section{Nut and kernel qualitative traits affected by WHF}

Non-infested nuts had more or less bright shells with cultivar-specific colour, without darkness, which was estimated by a mean score within a range of between 1.01 ('Fernor') and 1.59 ('Elit') (Table 2). Bright to light-brown kernels were normally developed, shriveled and mouldy kernels appeared only in traces. After WHF infestation, both the shells and the kernels became darkened. Similar consequences have been previously described by many researchers, such as Duso and Dal Lago (2006), Coates (2008), Samietz et al. (2012). Black coloration was due to black-coloured tannins, which were released in response to WHF larvae feeding on the green husk, and coloured the walnut shell first. After entering through the shell suture or through the stem end, where the structure of the lignified shell is less dense, they coloured the kernel as well.

Internal damage depended on the infestation time with a late infestation resulting in less than a quarter of the shell and kernel surface being darkened (mean scores of 2.2 for the shell and 1.6 for the kernel), while an early infestation resulted in an almost completely darkened shell and about half of the kernel surface darkened (mean scores of 3.5 and 2.6 , respectively). Kernel darkness significantly increased in early-infested nuts compared to late-infested and healthy ones. The same relationship was ascertained when observing mouldy and shriveled kernels.

The results also show that the severity of internal damage due to WHF is strongly cultivar-dependent. A late WHF attack strongly affected only 'Rasna' and 'A-117' cultivars, where $46 \%$ and $61 \%$ of the nuts had between one-quarter and a half of the shells darkened. The shell darkness of the early-infested nuts of the cultivars 'A-117', 'Chandler', 'Elit', 'Fernette', 'G-139' and 'Rasna' were estimated by scores from 3.58 to 3.83 (Table 2). In more detail, 48\% ('Fernette'), 53\%
('Rasna'), 58\% ('G-139'), 63\% ('A-117'), 64\% ('Chandler') and $67 \%$ ('Elit') of the nuts had more than half the shell surface darkened (Figure 4).

The cultivars 'A-117' and 'Rasna' had the largest and heaviest nuts amongst those studied (Table 1). A preference of the WHF to attack large nuts more frequently than small ones was first described by Coates (1994). This was confirmed by Papaj (2005), who reported that large nuts promote egg maturation more than small nuts. The phenomenon was additionally explained by Guillen et al. (2011), who found that the nut size significantly affects the weight of the WHF pupae as well as the longevity of adults and the length of a diapause. Large and heavy nuts are preferred by WHF females for oviposition because they favour offspring performance and development compared with smaller nuts. According to Van Steenwyk et al. (2013), small nuts are less attractive, offering a decreased surface area for WHF egg deposition in comparison with large nuts, providing a positive correlation between nut weight and the total amount of stings and stings with eggs.

Bright kernels without or with a very small darkened surface were found within non-infested nuts, estimated with scores from 1.01 ('Fernor', 'G-139') to 1.37 ('Elit') (Table 2). With an early infestation, only from 1.3\% ('A-117') up to $31.5 \%$ ('Fernette') of the kernels remained without any darkness (Figure 5) compared to late infestation, where the kernels preserved an unchanged and cultivar-specific colour within a range from $12.5 \%$ ('Rasna') to $70 \%$ ('Fernette'). As explained before, tannins, which are synthesized during WHF larval feeding and destroyed the nut husk, pass through the shell to the kernel, resulting in their darkening. Approximately 40 days' development of the pest, from the egg to the larvae stage, takes place in early-infested nuts. As a result, the husk is completely destroyed, producing high amounts of tannins, which strongly colour both the shells and the kernels. In contrast, late-infested nuts frequently mature before the ending of the larvae's development. In such a case, less tannins are produced and the coloration of the shell and the kernel tissue is weaker. As Figure 7 shows, only between 
TABLE 2. Damage levels of nut shells and kernels caused by WHF in ten walnut cultivars (means \pm SE).

\begin{tabular}{|c|c|c|c|c|c|c|}
\hline Cultivar & $\begin{array}{c}\text { WHF } \\
\text { infestation }\end{array}$ & $\begin{array}{c}\text { Shell } \\
\text { darkness }(1 / 2 / 3 / 4)\end{array}$ & $\begin{array}{c}\text { Kernel } \\
\text { darkness }(1 / 2 / 3 / 4)\end{array}$ & $\begin{array}{c}\text { Kernel } \\
\text { colour }(1 / 2 / 3 / 4)\end{array}$ & $\begin{array}{c}\text { Shriveled } \\
\text { kernels }(1 / 2 / 3)\end{array}$ & $\begin{array}{c}\text { Mouldy } \\
\text { kernels (1/2) }\end{array}$ \\
\hline A-117 & $\mathrm{H}^{*}$ & $1.57 \pm 0.06 \mathrm{a}$ & $1.35 \pm 0.07 a$ & $1.60 \pm 0.08 \mathrm{a}$ & $1.21 \pm 0.05 a$ & $1.18 \pm 0.06 a$ \\
\hline A-117 & L & $2.65 \pm 0.06 b$ & $1.79 \pm 0.07 b$ & $2.02 \pm 0.08 b$ & $1.24 \pm 0.05 a$ & $1.51 \pm 0.06 b$ \\
\hline A-117 & $E$ & $3.63 \pm 0.06 c$ & $2.49 \pm 0.07 c$ & $2.47 \pm 0.08 \mathrm{c}$ & $1.31 \pm 0.05 a$ & $1.65 \pm 0.06 b$ \\
\hline Chandler & $\mathrm{H}$ & $1.07 \pm 0.05 a$ & $1.03 \pm 0.09 a$ & $1.08 \pm 0.09 a$ & $1.09 \pm 0.06 \mathrm{a}$ & $1.00 \pm 0.05 a$ \\
\hline Chandler & $L$ & $2.08 \pm 0.05 b$ & $1.56 \pm 0.09 b$ & $1.59 \pm 0.09 b$ & $1.10 \pm 0.06 a$ & $1.19 \pm 0.05 b$ \\
\hline Chandler & $E$ & $3.59 \pm 0.05 c$ & $3.14 \pm 0.09 c$ & $2.92 \pm 0.09 \mathrm{c}$ & $1.95 \pm 0.06 b$ & $1.72 \pm 0.05 c$ \\
\hline Cisco & $\mathrm{H}$ & $1.06 \pm 0.06 a$ & $1.11 \pm 0.11 \mathrm{a}$ & $1.16 \pm 0.11 \mathrm{a}$ & $1.09 \pm 0.09 a$ & $1.01 \pm 0.04 \mathrm{a}$ \\
\hline Cisco & L & $2.02 \pm 0.06 b$ & $1.83 \pm 0.11 b$ & $1.81 \pm 0.11 b$ & $1.56 \pm 0.09 b$ & $1.15 \pm 0.04 b$ \\
\hline Cisco & $\mathrm{E}$ & $3.29 \pm 0.06 c$ & $2.68 \pm 0.11 \mathrm{c}$ & $2.63 \pm 0.11 c$ & $1.83 \pm 0.09 c$ & $1.47 \pm 0.04 c$ \\
\hline Elit & $\mathrm{H}$ & $1.59 \pm 0.06 a$ & $1.37 \pm 0.08 \mathrm{a}$ & $1.73 \pm 0.08 \mathrm{a}$ & $1.30 \pm 0.07 a$ & $1.15 \pm 0.05 a$ \\
\hline Elit & L & $2.30 \pm 0.06 b$ & $1.76 \pm 0.08 b$ & $1.68 \pm 0.08 \mathrm{a}$ & $1.23 \pm 0.07 a$ & $1.35 \pm 0.05 b$ \\
\hline Elit & $\mathrm{E}$ & $3.66 \pm 0.06 c$ & $2.57 \pm 0.08 c$ & $2.31 \pm 0.08 b$ & $1.36 \pm 0.07 a$ & $1.78 \pm 0.05 c$ \\
\hline Franquette & $\mathrm{H}$ & $1.03 \pm 0.06 \mathrm{a}$ & $1.10 \pm 0.09 \mathrm{a}$ & $1.27 \pm 0.09 a$ & $1.22 \pm 0.07 a$ & $1.01 \pm 0.04 \mathrm{a}$ \\
\hline Franquette & L & $2.01 \pm 0.06 b$ & $1.44 \pm 0.09 b$ & $1.76 \pm 0.09 b$ & $1.14 \pm 0.07 a$ & $1.14 \pm 0.04 b$ \\
\hline Franquette & $E$ & $3.24 \pm 0.06 \mathrm{c}$ & $2.65 \pm 0.09 c$ & $2.72 \pm 0.09 c$ & $1.76 \pm 0.07 b$ & $1.53 \pm 0.04 c$ \\
\hline Fernor & $\mathrm{H}$ & $1.01 \pm 0.04 \mathrm{a}$ & $1.01 \pm 0.08 \mathrm{a}$ & $1.14 \pm 0.08 \mathrm{a}$ & $1.23 \pm 0.07 a$ & $1.00 \pm 0.04 \mathrm{a}$ \\
\hline Fernor & L & $2.07 \pm 0.04 b$ & $1.38 \pm 0.08 b$ & $1.42 \pm 0.08 b$ & $1.21 \pm 0.07 a$ & $1.08 \pm 0.04 \mathrm{a}$ \\
\hline Fernor & $E$ & $3.26 \pm 0.04 c$ & $2.21 \pm 0.08 \mathrm{c}$ & $2.12 \pm 0.08 \mathrm{c}$ & $1.46 \pm 0.07 b$ & $1.45 \pm 0.04 b$ \\
\hline Fernette & $\mathrm{H}$ & $1.08 \pm 0.06 a$ & $1.10 \pm 0.09 a$ & $1.25 \pm 0.09 a$ & $1.27 \pm 0.08 a$ & $1.00 \pm 0.04 \mathrm{a}$ \\
\hline Fernette & L & $1.96 \pm 0.06 b$ & $1.33 \pm 0.09 a$ & $1.53 \pm 0.09 b$ & $1.13 \pm 0.08 a$ & $1.06 \pm 0.04 \mathrm{a}$ \\
\hline Fernette & $E$ & $3.83 \pm 0.06 c$ & $2.28 \pm 0.09 b$ & $2.41 \pm 0.09 c$ & $1.65 \pm 0.08 b$ & $1.37 \pm 0.04 b$ \\
\hline G-139 & $\mathrm{H}$ & $1.08 \pm 0.05 a$ & $1.01 \pm 0.07 a$ & $1.34 \pm 0.07 \mathrm{a}$ & $1.09 \pm 0.05 a$ & $1.03 \pm 0.04 \mathrm{a}$ \\
\hline G-139 & L & $2.09 \pm 0.05 b$ & $1.46 \pm 0.07 b$ & $1.78 \pm 0.07 b$ & $1.29 \pm 0.05 b$ & $1.33 \pm 0.04 b$ \\
\hline G-139 & $E$ & $3.58 \pm 0.05 c$ & $2.58 \pm 0.07 \mathrm{c}$ & $2.58 \pm 0.07 \mathrm{c}$ & $1.20 \pm 0.05 a b$ & $1.64 \pm 0.04 c$ \\
\hline Lara & $\mathrm{H}$ & $1.02 \pm 0.05 a$ & $1.02 \pm 0.08 \mathrm{a}$ & $1.21 \pm 0.08 \mathrm{a}$ & $1.08 \pm 0.06 a$ & $1.00 \pm 0.04 \mathrm{a}$ \\
\hline Lara & L & $2.07 \pm 0.05 b$ & $1.48 \pm 0.08 b$ & $1.56 \pm 0.08 b$ & $1.26 \pm 0.06 b$ & $1.13 \pm 0.04 b$ \\
\hline Lara & $E$ & $3.16 \pm 0.05 c$ & $2.41 \pm 0.08 \mathrm{c}$ & $2.59 \pm 0.08 \mathrm{c}$ & $1.46 \pm 0.06 c$ & $1.48 \pm 0.04 c$ \\
\hline Rasna & $\mathrm{H}$ & $1.37 \pm 0.06 a$ & $1.20 \pm 0.09 a$ & $1.41 \pm 0.07 \mathrm{a}$ & $1.25 \pm 0.07 a$ & $1.14 \pm 0.06 \mathrm{a}$ \\
\hline Rasna & L & $2.47 \pm 0.06 b$ & $2.24 \pm 0.09 b$ & $2.08 \pm 0.07 b$ & $1.33 \pm 0.07 a$ & $1.53 \pm 0.06 b$ \\
\hline Rasna & $E$ & $3.50 \pm 0.06 c$ & $2.65 \pm 0.09 c$ & $2.53 \pm 0.07 c$ & $1.57 \pm 0.07 b$ & $1.59 \pm 0.06 b$ \\
\hline
\end{tabular}

${ }^{*} \mathrm{H}$ - healthy nuts, without WHF infestation, $\mathrm{L}$ - late infestation, $\mathrm{E}$ - early infestation. Means with different letters within three rows related to the same cultivar are significantly different according to analysis of variance (ANOVA) and Duncan's Multiple Range Test $(P \leq 0.05)$.

4.1\% ('Fernette') and $28.4 \%$ ('Cisco') of the late-infested nuts had more than one quarter of the kernel surface darkened. Compared to these results, a much wider coloration was expressed in early-infested nuts, where between $37.5 \%$ ('Fernor') and 76.4\% ('Chandler') of the kernels had more than one quarter of the surface darkened.

Kernel colour of the studied cultivars varied from bright to light-brown, which are considered as extra- and first-class quality, to dark-brown, which can be sold as second-class quality, and even black, which makes the kernels unmarketable (UNECE, 2002). The impact of the WHF infestation on the kernel colour was shown as being cultivar- and infestation time-related. In a ten-cultivar average, a share of bright, cultivar-specific kernel colour decreased from $74 \%$ in non-infested nuts to $43 \%$ in late-infested nuts, and only $10 \%$ in early-infested nuts (Figure 6). Late infestation strongly affected the 'Cisco' cultivar, causing $17.6 \%$ dark brown and $12.2 \%$ black kernels. Dark-brown kernels were also more frequent in the cultivars 'Lara', with $12.3 \%$, 'Rasna', with $15.3 \%$, and 'A-117', with $16.7 \%$. High internal damage of the last two cultivars could be explained by the large size of their nuts and husk tissue. After WHF larvae feeding, a high tannin content that stained the kernel was assumed to be secreted from large husk tissue. In the cultivars 'Chandler', 'Fernor' and 'Cisco', which had between 86 and $92 \%$ of bright kernels in non-infested nuts, the share of bright kernels decreased from $20 \%$ to almost $40 \%$ after late WHF infestation. Furthermore, only 11\% ('Chandler'), 19\% ('Cisco') and 28\% ('Fernor') of the kernels preserved a bright colour after early WHF infestation and more than one-third of 'Franquette' and 'Chandler' kernels became black and completely inedible (Figure 6). It is possible that the shell of late-maturing cultivars was not completely lignified at the early WHF infestation. In our case, the shell of the early-infested 'Franquette' nuts was a little bit thinner than that of the non-infested nuts, which might have resulted in a heavier pest impact on the kernel quality.

Furthermore, shriveled kernels appeared frequently owing to the WHF infestation, which has already been proven by Coates and Van Steenwyk (2005) and Coates (2004, 2005, 2008). The pest larvae injured the conductive tissue of the nut, which led to abnormal development and shriveling of the kernels. The share of the shriveled kernels was shown as cultivar- and WHF-infestation-time-dependent. The average share of the shriveled kernels significantly increased from that of non-infested nuts $(14.2 \%)$ to the late-infested 


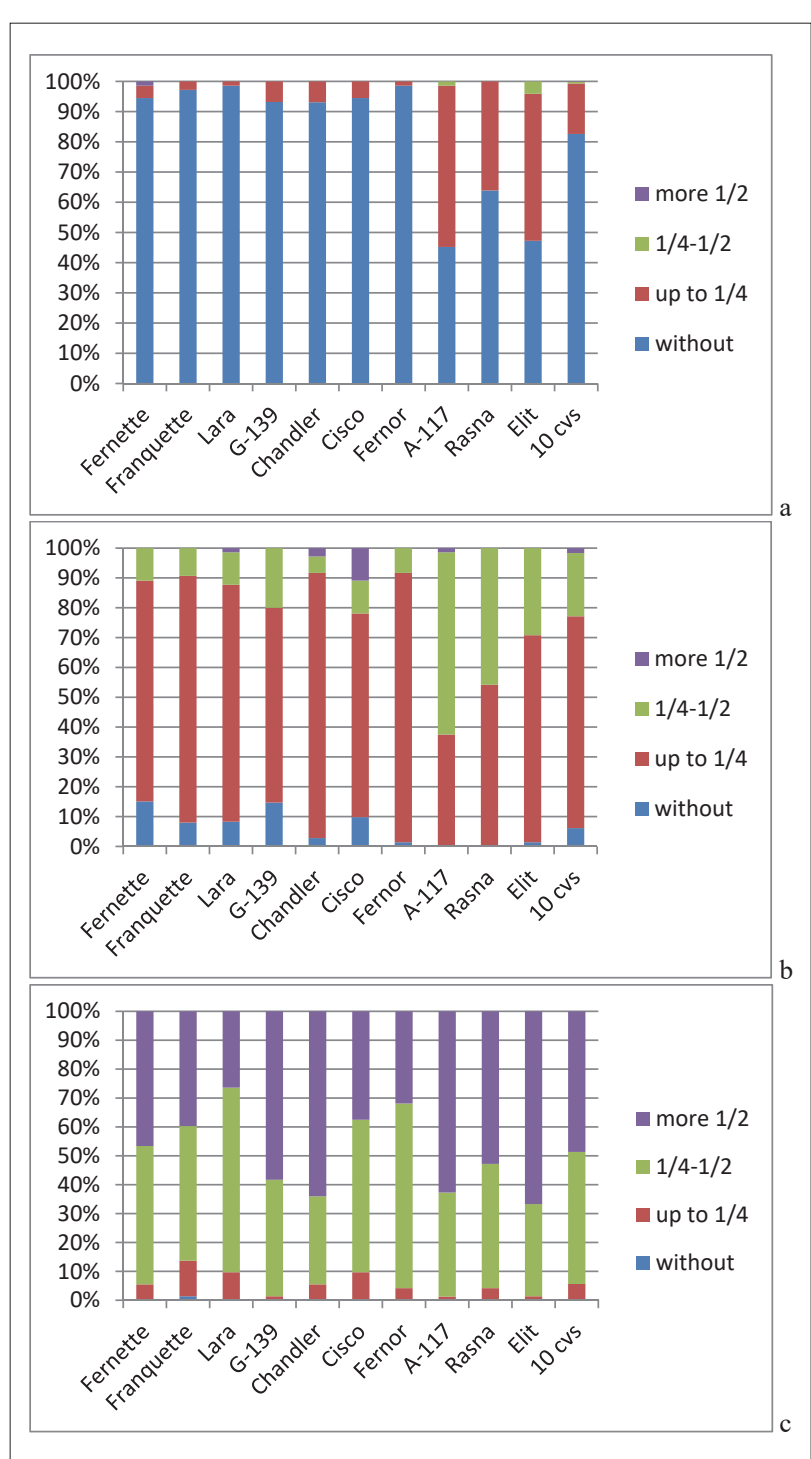

FiguRE 4. A mean share between four levels of darkened shell surface due to WHF in non- infested nuts (a), late-infested (b) and early-infested ones (c) for ten walnut cultivars.

(21.4\%) and early-infested ones (40.0\%) (Figure 7). At an early infestation, we observed more than two-thirds normally developed kernels in the cultivars 'Fernor', 'A-117', 'Elit' and 'G-139', compared to the 'Chandler' and 'Cisco' cultivars, where approximately one-third of the kernels were shriveled (Figure 7).

Similarly to tannins, fungi which appear on the early-infested nuts as saprofits, contaminated the kernels, producing mould and making them inedible, which is in agreement with Duso and Dal Lago (2006). As Figure 8 shows, between 5.5\% ('Fernette') and 45.8\% ('A-117', 'Rasna') of the late-infested nuts had mouldy kernels. Compared to them, an early WHF infestation caused a much higher rate of mouldiness, varying from 37\% ('Fernette') to 75\% ('Elit').

In general, early-season infestation caused significantly higher levels of damage compared to late-season infestation. Amongst ten studied cultivars, 'Cisco' was the most evident exception, having more empty nuts, a higher percentage of darkened shells and kernels, as well as more shriveled kernels after late WHF infestation compared to early infestation. In Slovene conditions, the 'Cisco' nuts mature in mid-season. According to Opp et al. (2001), such cultivars are more sus-

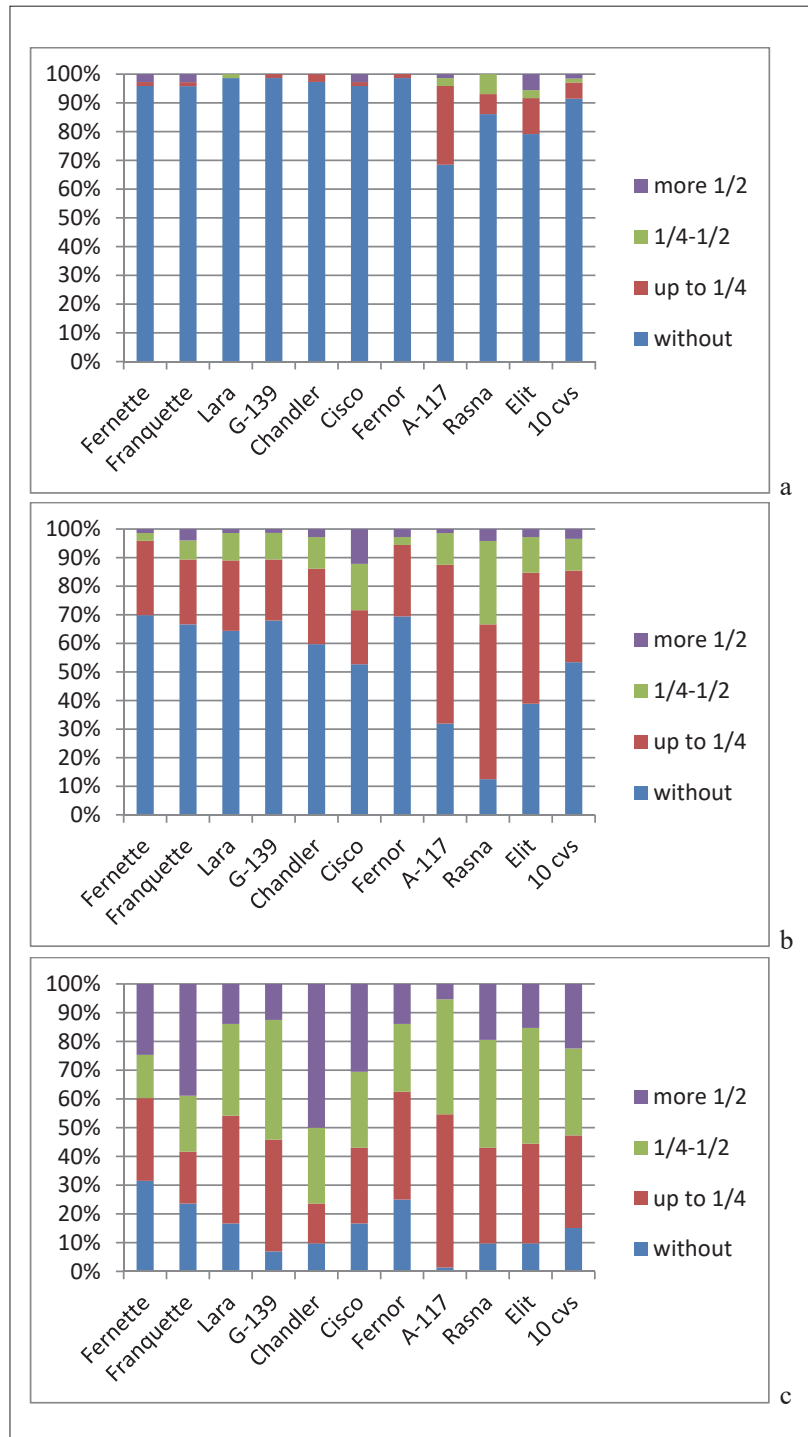

FIGURE 5. A mean share between four levels of darkened kernel surface due to WHF in non-infested nuts (a), late-infested (b) and early-infested ones (c) for ten walnut cultivars.

ceptible to WHF compared to the early-season ones.

Early-leafing cultivars with large nuts, such as 'A-117' and 'Rasna', showed no in-shell weight reduction due to WHF infestation, while more than $50 \%$ of the nuts had dark shells and kernels with a high level of mould due to early infestation. These results are in agreement with Coates (1994), Guillen et al. (2011), and Van Steenwyk et al. (2013), who reported that WHF prefers large and heavy nuts. However, our results cannot be considered the rule. Namely, similar consequences as those of 'A-117' and 'Rasna' were observed in the medium-sized nut cultivar 'G-139', as well as in the smaller-sized nut cultivar 'Elit'. Both 'G-139' and 'Elit' are early-maturing cultivars, which in most years escape damage (Opp et al. 2001). In our case, early maturation and smaller nut size did not contribute to less WHF damage.

A weak correlation between low susceptibility to WHF and small nut size was also ascertained in 'Chandler'. As a medium-leafing lateral-fruiting cultivar, 'Chandler' usually achieves a high crop in our experimental orchard, but in the absence of irrigation the in-shell nuts very seldom exceed $9 \mathrm{~g}$. The impact of an early WHF attack on external quality was represented by a reduction of $13 \%$ of in-shell weight 


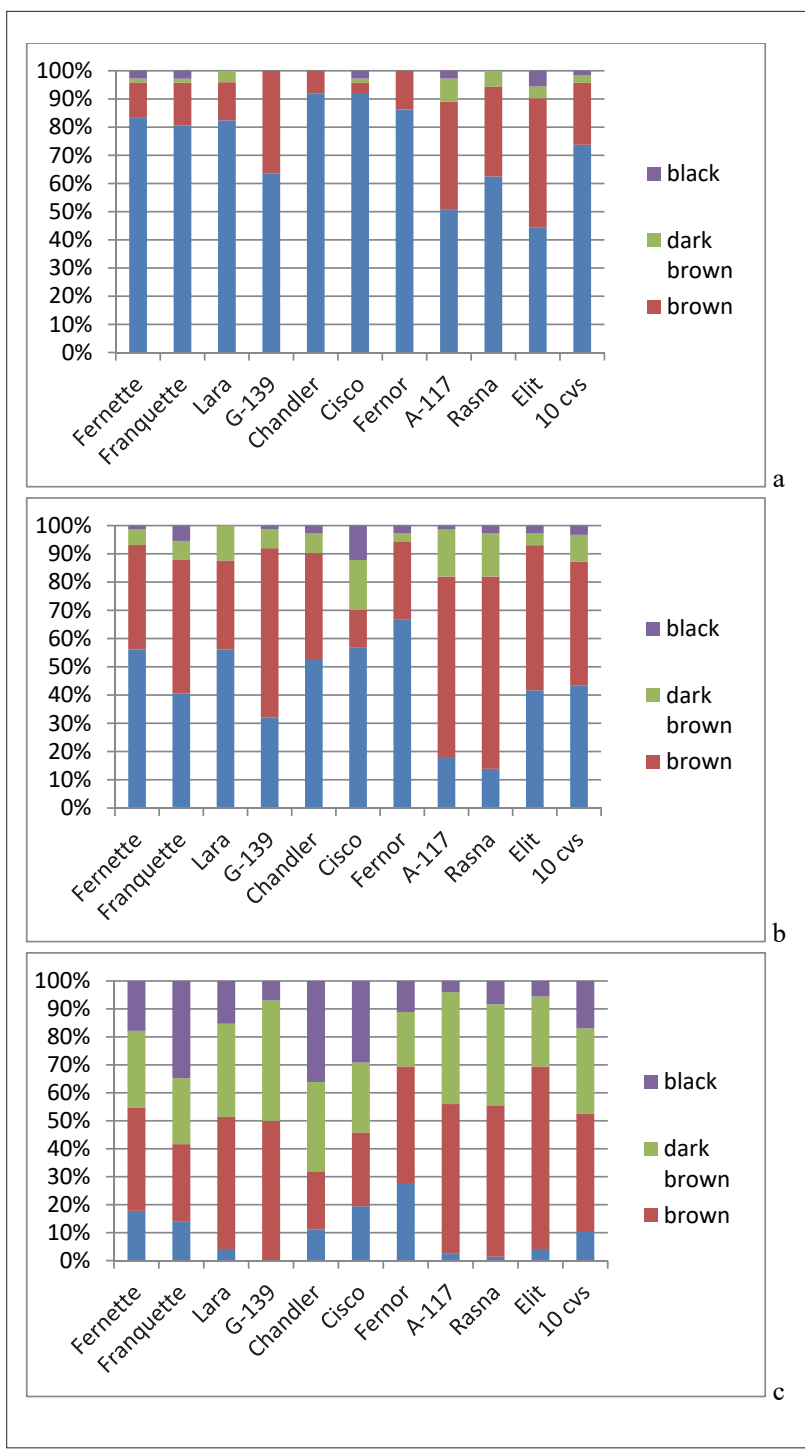

FiguRE 6. A mean share between four kernel colors due to WHF in non-infested nuts (a), late-infested (b) and earlyinfested ones (c) for ten walnut cultivars.

and $18 \%$ of the nuts being baby ones. Two-thirds of the infested nuts had more than one-quarter of the shell surface darkened, compared to $39 \%$ of stained shells reported by Coates (2008). Internal damage to the 'Chandler' cultivar was manifested as $22 \%$ of poorly filled or empty kernels, $50 \%$ of the kernels with more than a half of the surface darkened and $36 \%$ of completely black kernels. A high share of shriveled and mouldy kernels was also observed. Our results are in agreement with Opp et al. (2001), who considered the 'Chandler' cultivar as being highly susceptible to WHF. On the contrary, we cannot confirm Coates (2004) and Coates and Van Steenwyk (2005), who mentioned that 'Chandler' is less susceptible or even appears to be somewhat tolerant to WHF, because its infestation begins later in the season than in other cultivars. Moreover, the morphological and biochemical defence mechanisms of the 'Chandler' cultivar were recently discovered by US researchers. The first is a high trichome density, which is negatively correlated with the total amount of stings with eggs found on the nuts over a season (Van Steenwyk et al., 2013, 2014a) and the second is the leaf volatile methyl benzoate, which has a repellent effect on the WHF (Van Steenwyk et al., 2015, 2016).

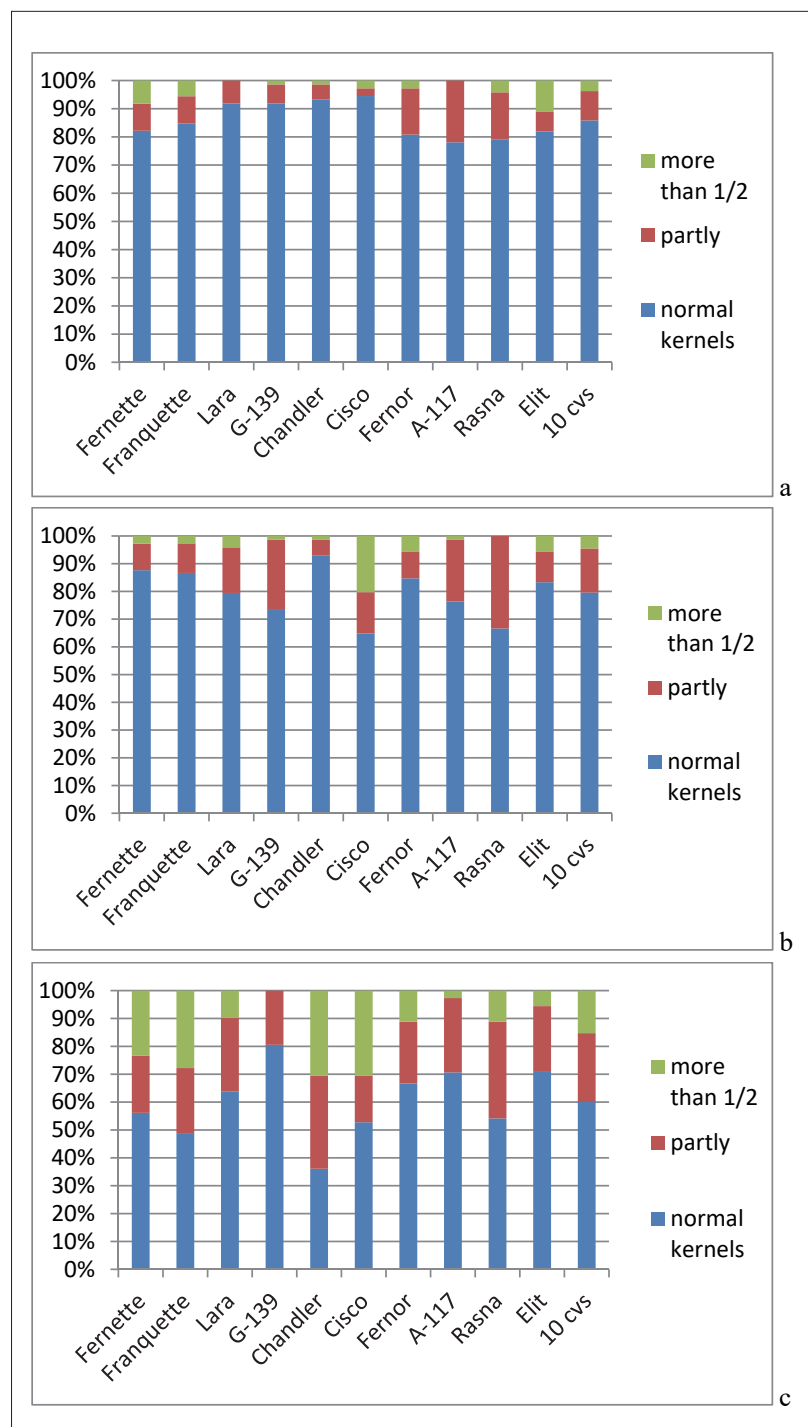

FigURE 7. A mean share between three levels of kernel shriveledness due to WHF in non-infested nuts (a), late-infested (b) and early-infested ones (c) for ten walnut cultivars.

Furthermore, a high WHF susceptibility of the cultivar 'Franquette' was observed and compared favourably with results obtained in Californian orchards, and described by Coates (2004) and Van Steenwyk et al. (2013). Owing to early WHF infestation, the in-shell and kernel weight was reduced by $17 \%$ and $22 \%$, respectively. There was a total of $17 \%$ of baby nuts, and one-third of poorly filled or empty kernels. A total of $58 \%$ of the kernels had more than a quarter of their surface darkened, and one-third of the kernels became completely black.

Another commercially important, medium to large-sized French cultivar, 'Lara', was reduced in its in-shell nut size, producing $11 \%$ baby nuts at late infestation and $17 \%$ at early infestation. A quarter of early-infested nuts had more than a half of their shell surface darkened, and contained poorly filled or empty kernels. Most of them had a brown to darkbrown pellicle. Ten percent of the nuts had more than half of their kernels shriveled, and in just under half of them traces of mould were found.

When summarizing the 'Fernor' cultivar, which is a hybrid of the 'Franquette' and 'Lara' cultivars (Germain et al., 1996), we saw that the in-shell size was reduced less than 


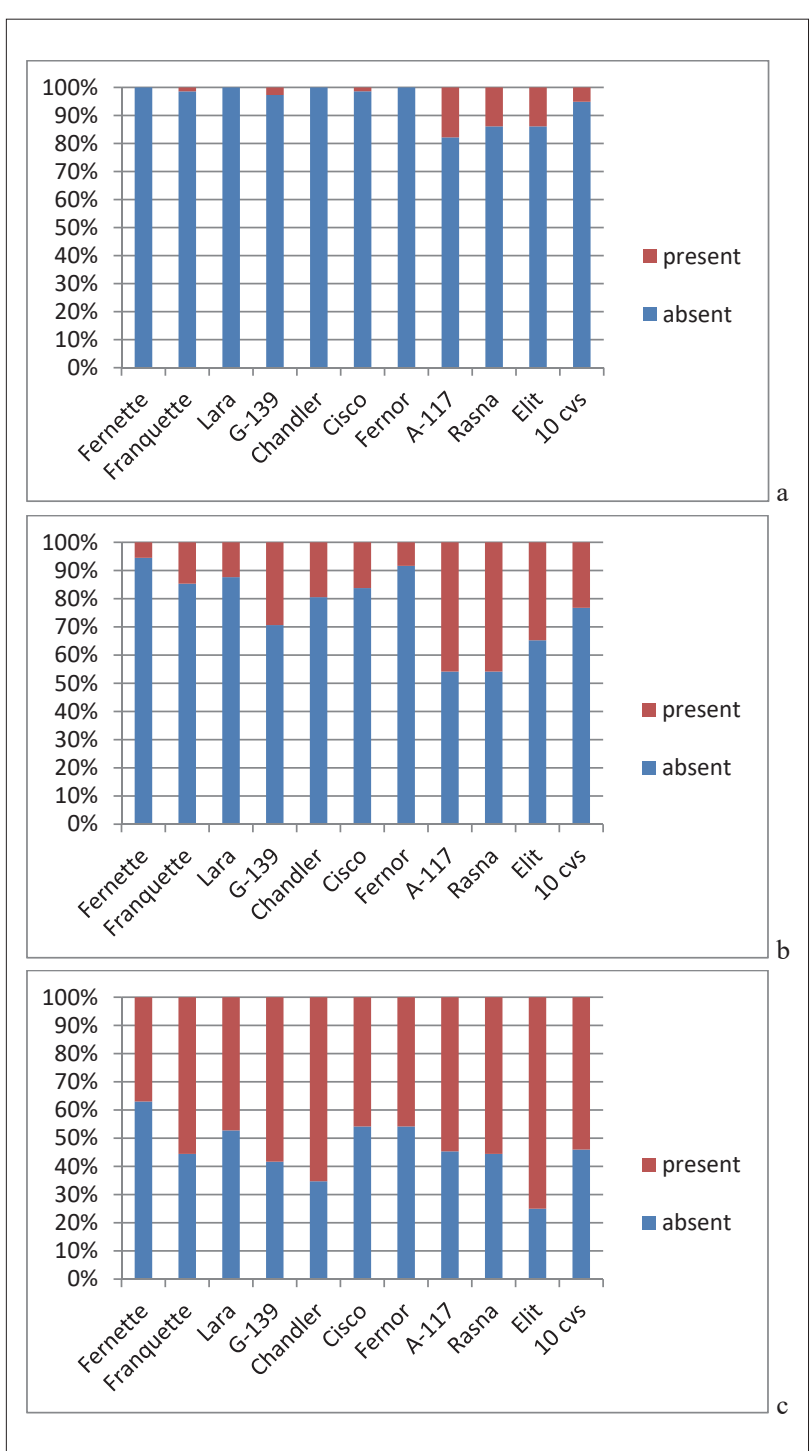

FIGURE 8. A mean share between mouldy and healthy kernels due to WHF in non-infested nuts (a), late-infested (b) and early-infested ones (c) for ten walnut cultivars.

in their parental cultivars, having only $7 \%$ of baby nuts after early WHF infestation. Eighty-six per cent of the kernels were normally developed, compared to 'Lara' with $76 \%$ and 'Franquette' with $67 \%$. The 'Fernor' shell surface was darkened in a similar way to the 'Lara' shells, but less than the 'Franquette' ones. A quarter of the kernels remained without any darkness, and more than two-thirds of the kernels preserved a light-brown to brown pellicle in spite of early WHF infestation. The 'Fernor' share of shriveled and mouldy kernels was similar to that of 'Lara' and lower than that of the 'Franquette' nuts.

In the 'Fernette' cultivar, which originates from the same breeding combination as 'Fernor' (Germain et al., 1996), we observed significant nut and kernel weight reduction, similar to that seen in the 'Franquette' cultivar. There were 15\% of baby nuts, one-fifth of empty or poorly filled kernels and one-third of mouldy kernels. Shell-darkened surface exceeded those observed in both parental cultivars. Amongst all the studied cultivars, 'Fernette' expressed the highest share of kernels (31.5\%) without any darkness. More than a half of early-infested nuts maintained light-brown to brown kernels, and $18 \%$ of the kernels had a black-coloured pellicle.
'Fernette' displayed more shriveled kernels than 'Lara', but fewer than 'Franquette', having the lowest percentage of mould among the ten cultivars. As reported by Guillén et al. (2011), fewer WHF larvae were found in 'Fernette' husk tissue compared to 'Franquette', which might be a reason for the lower damage level revealed for 'Fernette' in our investigation.

\section{Conclusion}

Our results show that non-infested walnuts, which were produced according to standard proceedings, including regular harvest, cleaning and immediate drying, had good external and internal quality, with more or less bright, cultivar-specific shell and kernel colour, respectively. Owing to the WHF infestation, the green husks were darkened and softened, but intact, and easily distinguished from wet black lesions caused by Xanthomonas arboricola pv. juglandis and dry and hard black apical lesions, caused by brown apical necrosis. Moreover, the in-shell and kernel weight was reduced, the shells and kernels became darkened or even black, and kernels could be shriveled and even mouldy as a result of the WHF infestation. 'Franquette' and 'Chandler' cultivars showed the highest damage level, while 'Fernor' preserved the best external and internal quality in spite of the WHF infestation. Furthermore, differences in susceptibility to the WHF within a single cultivar were observed, depending on the infestation time. Moreover, the differences in WHF susceptibility might be ascribed not only to genetic determinism, but also to environmental conditions, taking into account that some of our results relate, albeit weakly, to those previously obtained under various growing conditions.

\section{Acknowledgments}

This work was conducted within a project V4-1067, which was founded by Slovenian Research Agency, the Ministry of Agriculture, Forestry and Food, and the Ministry of Environment and Spatial Planning, and was a part of the program Horticulture No. P4-0013-0481, granted by the Slovenian Research Agency (ARRS).

\section{References}

Aluja, M., Guillén, L., Rull, J., Höhn, H., Frey, J., Graf, B., and Samietz, J. (2011). Is the Alpine divide becoming more permeable to biological invasions as a result of global-warming? - Insights on the invasion and establishment of the walnut husk fly, Rhagoletis completa (Diptera: Tephritidae) in Switzerland. Bull. Entomol. Res. 101, 451465. https://doi.org/10.1017/S0007485311000010.

Anderson, K.K., and Lampinen, B. (2008). Use of Surround ${ }^{\circledR}$ WP crop protectant on walnuts. Grower News, p. 4-5.

Australian Tree Nut Industry (2017). Healthy Handful Daily. Nuts for Life. https://www.nutsforlife.com.au/media/healthy-handful (assessed June, 2018).

Bao, Y., Hu, F.B., Giovannucci, E.L., Wolpin, B.M., Stampfer, M.J., Willett, W.C., and Fuchs, C.S. (2013). Nut consumption and risk of pancreatic cancer in women. Br. J. Cancer 109, 2911-2916. https:// doi.org/10.1038/bjc.2013.665.

Barić, B., Pajač Živković, I., Matošević, D., Šubić, M., Voight, E., and Tóth, M. (2015). Rhagoletis completa (Diptera; Tephritidae) distribution, flight dynamics and influence on walnut kernel quality in the continental Croatia. Poljoprivreda 21(1), 53-58. https://doi. org/10.18047/poljo.21.1.9.

Bes-Rastrollo, M., Wedick, N.M., Martinez-Gonzalez, M.A., Li, T.Y., Sampson, L., and Hu, F.B. (2009). Prospective study of nut consumption, long-term weight change, and obesity risk in women. 
Am. J. Clin. Nutr. 89(6), 1913-1919. https://doi.org/10.3945/ ajcn.2008.27276

Bujdosó, G., Véegvári, G., Hajnal, V., Fiszek, G., and Tóth, M. (2014). Phenolic profile of the kernel of selected Persian walnut Uuglans regia L.) cultivars. Not. Bot. Hort. Agrobot. 42(1), 24-29. https://doi. org/10.15835/nbha4219400.

Carey, A.N., Fisher, D.R., Joseph, J.A., and Shukitt-Hale, B. (2013). The ability of walnut extract and fatty acids to protect against the deleterious effects of oxidative stress and inflammation in hippocampal cells. Nutr. Neurosci. 16(1), 13-20. https://doi.org/10. 1179/1476830512Y.0000000023.

Carsten, L.D., and Papaj, D.R. (2005). Effects of reproductive state and host resource experience on mating decisions in a walnut fly. Behav. Ecol. 16, 528-533. https://doi.org/10.1093/beheco/ari026.

Chen, C.-Y.O., and Blumberg, J.B. (2008). Phytochemical composition of nuts. Asia Pac. J. Clin. Nutr. 17 (S1), 329-332.

Coates, W.W. (1994). Relating walnut husk fly damage to nut size. Walnut Research Reports (Sacramento, CA, USA: Walnut Marketing Board), p. 190-193.

Coates, W.W. (2004). Walnut husk fly: varietal susceptibility and quality observations. Walnut Research Reports (Sacramento, CA, USA: Walnut Marketing Board), p. 179-181.

Coates, W.W. (2005). Walnut husk fly: varietal susceptibility and its impact on nut quality. Walnut Research Reports (Sacramento, CA, USA: Walnut Marketing Board), p. 157-160.

Coates, W.W. (2008). The impact of walnut husk fly infestation on walnut quality: 2007-08 harvest seasons. Walnut Research Reports (Sacramento, CA, USA: Walnut Marketing Board), p. 111-115.

Coates, W.W., and Van Steenwyk, R.A. (2005). Development of organic control measures for walnut husk fly in English walnuts, cultivar susceptibility, and impacts on nut quality from infestation. HortScience 40, 993-1147. https://doi.org/10.21273/ HORTSCI.40.4.1103C

Colaric, M., Veberic, R., Solar, A., Hudina, M., and Stampar, F. (2005) Phenolic acids, syringaldehyde, and juglone in fruits of different cultivars of Juglans regia L. J. Agric. Food Chem. 53, 6390-6396. https://doi.org/10.1021/jf050721n.

Cosmulescu, S., Baciu, A., Achim, G., Botu, M., and Trandafir, I. (2009) Mineral composition of fruits in different walnut (Juglans regia L.) cultivars. Not. Bot. Hort. Agrobot. 37(2), 156-160.

Duso, C., and Dal Lago, G. (2006). Life cycle, phenology and economic importance of the walnut husk fly Rhagoletis completa Cresson (Diptera: Tephritidae) in northern Italy. Ann. Soc. Entomol. Fr. (n.s.) 42(2), 245-254. https://doi.org/10.1080/00379271.2006.1070062 8.

Germain, E., Charlot, G., and Prunet, J.P. (1996). 'Fernor' et 'Fernette' deux nouvelles variétés an atout pour la nuciculture Française de l'an 2000. Infos - Ctifl 124, 27-29.

Guillén, L., Aluja, M., Rull, J., Höhn, H., Schwizer, T., and Samietz, J. (2011). Influence of walnut cultivar on infestation by Rhagoletis completa: behavioral and management implications. Entom. Exp. Appl. 140, 207-217. https://doi.org/10.1111/j.15707458.2011.01157.x

Hislop, R.G., Riedl, H., and Joos, J.L. (1981). Control of the walnut husk fly with pyrethroids and bait. Calif. Agric. 35(9/10), 23-25.

Kasana, A., and Aliniazee, M.T. (1996). Seasonal phenology of the walnut husk fly, Rhagoletis completa Cresson (Diptera: Tephritidae). Can. Entom. 128(3), 377-390. https://doi.org/10.4039/Ent1283773.

Laznik. Ž., and Trdan, S. (2013). Možnosti varstva oreha (Juglans spp.) pred orehovo muho (Rhagoletis completa Cresson, 1929 Diptera:
Tephritidae) s poudarkom na biotičnem zatiranju škodljivca. Acta Agric. Slov. 101, 287-292. https://doi.org/10.2478/acas-20130024 .

Lethmayer, C. (2008). First evidence of the walnut husk fly (Rhagoletis completa) in Austria. Proc. $7^{\text {th }}$ Int. Conf. on Integrated Fruit Production, Avignon, France, 211 pp.

Martinez, M.L., Labuckas, D., Lamarque, A.L., and Maestri, D.M. (2010). Walnut (Juglans regia L.): genetic resources, chemistry, byproducts. J. Sci. Food Agric. 90,1959-1967. https://doi.org/10.1002/ jsfa.4059.

Merz, B. (1991). Rhagoletis complete Cresson und Rhagoletis indifferens Curran, zwei wirtschaftlich bedeutende Nordamerikanische Früchtfliegen, neu für Europa (Diptera:Tephritidae). Mitt. Schweiz. Entomol. Ges. 64, 55-57.

Miklavc, J., Matko, B., Mesl, M., Stampar, F., and Solar, A. (2010). Walnut husk fly (Rhagoletis completa Cresson) in Slovenia. Seasonal dynamics as followed in Maribor (NE). Acta Hortic. 861, 389-394. https://doi.org/10.17660/ActaHortic.2010.861.53.

Milles, N.J., Emery, S., and Buchner, R. (2015). Phenology model for walnut husk fly. Walnut Research Reports (California Walnut Board), $257 \mathrm{pp}$

Miraliakbari, H., and Shahidi, F. (2008). Lipid class compositions, tocopherols and sterols of tree nut oils extracted in different solvents. J. Food Lipids 15(1), 81-96. https://doi.org/10.1111/ j.1745-4522.2007.00104.x

Olson, WH., and Buchner, R.P. (2002). Leading edge of plant protection for walnuts. HortTech 12, 615-618. https://doi.org/10.21273/ HORTTECH.12.4.615.

Opp, S., Zermeňo, J., Garrick, C., Mooney, B., and Wilkerson, C. (2001). Timing and susceptibility of walnut cultivars to walnut husk fly attack - 3 years of emergence patterns. Walnut Research Reports (Sacramento, Cal., USA: Walnut Marketing Board), p. 379-382.

Pan, A., Sun, Q., Manson, J.E., Willett, W.C., and Hu, F.B. (2013). Walnut consumption is associated with lower risk of type 2 diabetes in women. J. Nutr. 143(4), 512-518. https://doi.org/10.3945/ jn.112.17217.1.

Papaj, D.R. (2005). Ovarian dynamics in relation to host quality in the walnut-infesting fly, Rhagoletis juglandis. Funct. Ecol. 19(3), 396404. https://doi.org/10.1111/j.1365-2435.2005.00993.x.

Riedl, H., Barnett, W.W., Coates, W.W., Coviello, R., Joos, J., and Olson, W.H. (1989). Walnut husk fly (Diptera: Tephritidae) - evaluation of traps for timing of control measure and for damage predictions. J. Econ. Entomol. 82(4), 1191-1196. https://doi.org/10.1093/ jee/82.4.1191.

Ros, E. (2015). Nuts and CVD. Br. J. Nutr. 113, S111-120. https://doi. org/10.1017/S0007114514003924.

Samietz, J., Schwizer, T., Höhn, H., Linder, C., Aluja, M., and Guillén, L. (2012). Noircissement des noix dû aux mouches et aux maladies: importance du choix variétal. Rev. Suisse Viticult., Arboricult., Horticult. 44(2), 88-93.

Sarles, L., Verhaeghe, A., Francis, F., and Verheggen, F.J. (2015). Semiochemicals of Rhagoletis fruit flies: Potential for integrated pest management. Crop Protect. 78, 114-118. https://doi.org/10.1016/j. cropro.2015.09.001.

Seljak, G., and Žežlina, I. (1999). Appearance and distribution of walnut husk fly (Rhagoletis completa Cresson) in Slovenia. In Lectures and Papers of the $4^{\text {th }}$ Slovenian Conference on Plant Protection, Portorož (Slo), March 3-4, J. Maček, ed. (Ljubljana: Plant Protection Society of Slovenia), p. 231-238.

Slatnar, A., Mikulic-Petkovsek, M., Stampar, F., Veberic, R., and Solar, A. (2015). Identification and quantification of phenolic compounds in kernels, oil and bagasse pellets of common walnut Uuglans 
regia L.). Food Res. Int. 67, 255-263. https://doi.org/10.1016/j. foodres.2014.11.016

Solar, A., and Stampar, F. (2011). Characterisation of selected hazelnut cultivars: phenology, growing and yielding capacity, market quality and nutraceutical value. J. Sci. Food Agric. 91, 1205-1212. https://doi.org/10.1002/jsfa.4300.

Solar, A., Miklavc, J., Seljak, G., Mešl, M., Matis, G., Matko, B., and Pliberšek, T. (2007). First experiences with control of walnut husk fly (Rhagoletis completa Cresson) in northeast part of Slovenia. In Lectures and Papers of the $8^{\text {th }}$ Slovenian Conference on Plant Protection, Radenci, March 6-7, J. Maček, ed. (Ljubljana: Plant Protection Society of Slovenia), p. 220-224.

Tuba, K., Schuler, H., Stauffer, C., and Lakatos, F. (2012). A nyugati dióburok-fúrólégy (Rhagoletis completa Cresson 1929 - Diptera: Tephritidae) megjelenése magyaroszágon. Növényvédelèm 48(9), 419-424.

UC (1993). Integrated Pest Management for Walnuts, $2^{\text {nd }}$ edn. (University of California, Div. Agric. Nat. Res.), Publ. 3270, p. 44-46.

UNECE (2002). Standard DDP-02 concerning the marketing and commercial quality control of walnut kernels, 2002 edn. (New York and Geneva: United Nations), 13 pp.

US Food and Drug Administration (2017). Qualified Health Claims About Cardiovascular Disease Risk: Walnuts \& Heart Disease (Docket No. 02P-0292). https://www.fda.gov/Food/ IngredientsPackagingLabeling/LabelingNutrition/ucm073992. htm\#cardio (assessed January, 2018).

Van Steenwyk, R.A., and Barnett W.W. (1998). Insects and mite pests. In Walnut Production Manual, Publ. 3373, D.E. Ramos, ed., (Oakland, Cal., USA: University of California, Division of Agriculture and Natural Resources), p. 247-253.

Van Steenwyk, R.A., Verhaeghe, A., Leslie, C.A., Coates, W.W., Grant, J.A., and Hasey, J.K. (2013). Biology and control of walnut husk fly using reduced risk products, Walnut Research Reports (California Walnut Board), p. 199-213.

Van Steenwyk, R.A., Verhaeghe, A., Leslie, C.A., Coates, W.W., Grant, J.A., and Hasey, J.K. (2014a) .Biology and control of walnut husk fly using reduced risk products - 2014, Walnut Research Reports (California Walnut Board), p. 207-222.

Van Steenwyk, R.A., Novotny, L.M., Thayer, L., Weiss, G.B., Coates, W.W., Verhaeghe, A., Grant, J.A., and Hasey, J.K. (2014b). Evaluation of monitoring techniques for walnut husk fly. Acta Hortic. 1050, 263269. https://doi.org/10.17660/ActaHortic.2014.1050.35

Van Steenwyk, R.A., Leslie, C.A., Coates, W.W., Grant, J.A., and Hasey, J.K. (2015). Biology and control of walnut husk fly using reduced risk products - 2015, Walnut Research Reports (California Walnut Board), p. 243-255.

Van Steenwyk, R.A., Leslie, C.A., Coates, W.W., Grant, J.A., and Hasey, J.K. (2016). Biology and control of walnut husk fly using reduced risk products - 2016, Walnut Research Reports (California Walnut Board), p. 1-18.

Verhaeghe, A., Weydert, C., Chalaye, C., and Vericel, G. (2010). Control of walnut husk fly thanks to alternative methods. Acta Hortic. 861, 395-398. https://doi.org/10.17660/ActaHortic.2010.861.54.

Wu, G.L., Liu, Q.L., and Teixeira da Silva, J.A. (2009). Ultrastructure of pericarp and seed capsule cells in the developing walnut (Juglans regia L.) fruit. S. Afr. J. Bot. 75, 128-136. https://doi.org/10.1016/j. SAJB.2008.09.001.
Received: Aug. 22, 2018

Accepted: Nov. 28, 2018

Addresses of authors:

Anita Solar 1 ,*, Franci Stampar², Robert Veberic ${ }^{2}$ and

Stanislav Trdan ${ }^{3}$

${ }^{1}$ University of Ljubljana, Biotechnical Faculty, Department of Agronomy, Experimental Field for Nut Crops,

Vinarska 14, 2000 Maribor, Slovenia

${ }^{2}$ University of Ljubljana, Biotechnical Faculty, Department of Agronomy, Chair for Fruit, Wine and Vegetable Growing, Jamnikarjeva 101, 1000 Ljubljana, Slovenia

${ }^{3}$ University of Ljubljana, Biotechnical Faculty, Department of Agronomy, Chair of Phytomedicine, Agricultural Engineering, Crop Production, Pasture and Grassland Management, Jamnikarjeva 101, 1000 Ljubljana, Slovenia

* Corresponding author; E-mail: anita.solar@bf.uni-lj.si Tel./Fax: + 38622511755 


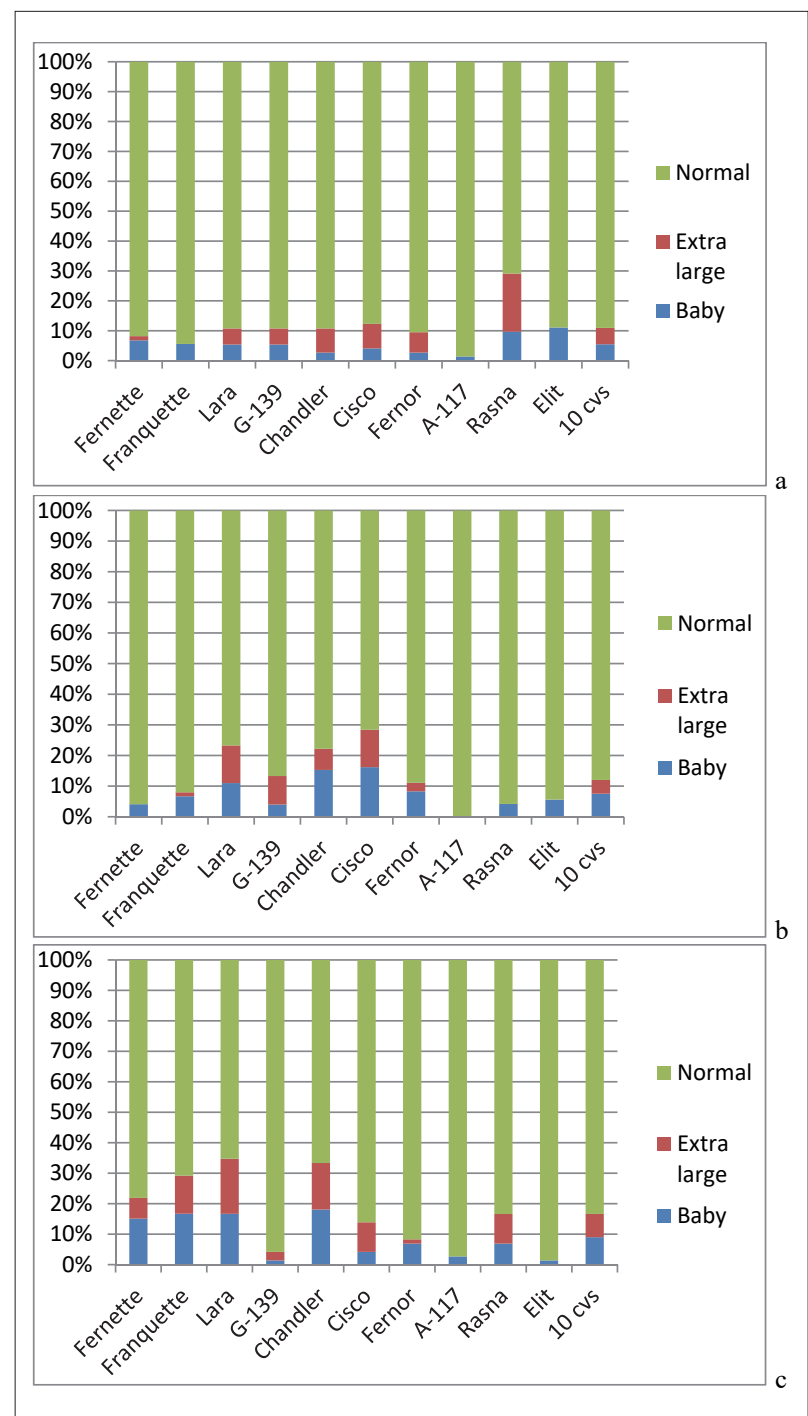

SUPPLEMENTAL INFORMATION - FigURE S1. A mean share between normal, extra-large and baby in-shell nut size in non-infested nuts (a), late-infested (b) and early-infested ones (c) for ten walnut cultivars.

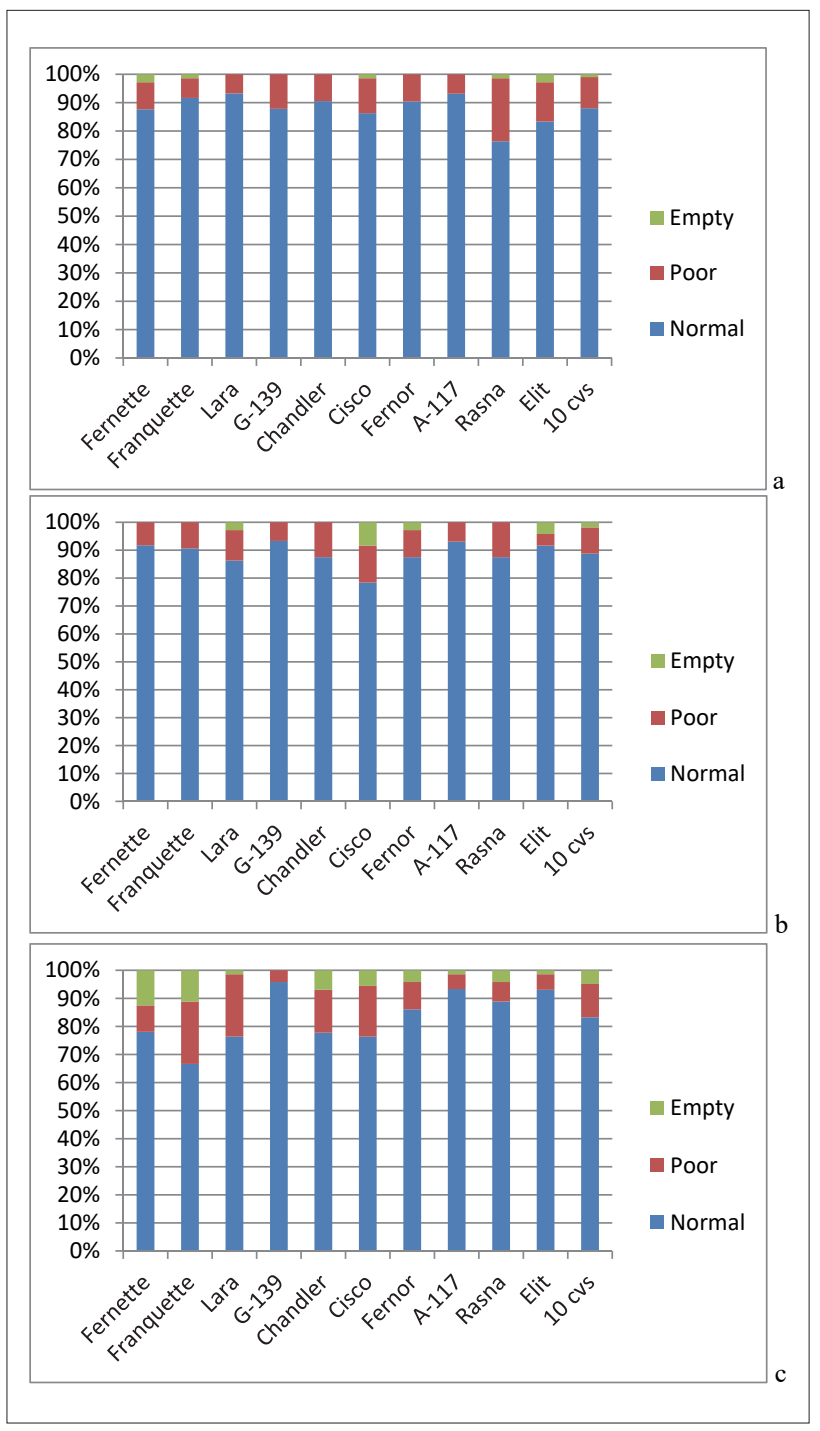

SUPPLEMENTAL INFORMATION - FiguRE S2. A mean share between normal, poorly filled and empty nuts in non-infested nuts (a), late-infested (b) and early-infested ones (c) for ten walnut cultivars. 